\title{
WATER SPREAD TEST ON IOT (Internet of Things) BASED AUTOMATIC IRRIGATION SYSTEM
}

\author{
Eko Noerhayati ${ }^{1}$, Anita Rahmawati ${ }^{2}$, Satriyo Yoga Wahyudi ${ }^{3}$ \\ ${ }^{1,2}$ Civil Engineering Department, University of Islamic Malang, Malang, 65144, Indonesia \\ ${ }^{3}$ Graduate School of Engineering and Faculty of Engineering, University of Islamic \\ Malang, Malang, 65144, Indonesia \\ E-mail: ekonoerhayati@unisma.ac.id
}

\begin{abstract}
This research is intended to determine the performance of the tools in the sprinkler irrigation system using controls (android). This activity was carried out in an experimental garden in the laboratory Enviro-Hydro of the Civil Engineering Faculty of Engineering, University of Islamic Malang, covering an area of $80 \mathrm{~m}^{2}$. There are two variables used as a reference for sprinkler performance, namely automatic and manual with each valve opening $45^{\circ}-90^{\circ}$, on 4 sprinklers installed on the land with a distance of $1 \mathrm{~m}$ each other. Water flows from 2 tadons that are placed parallel. The method used to analyze the data using the T test which compares the observation results of water distribution from automatic and manual sprinkler openings. The results of measuring the distribution of automatic and manual sprinkler water show that the results are not much different, only a difference of $1 \%$ so that the performance of both automatic and manual sprinklers has not different results.
\end{abstract}

Keywords: irrigation, sprinkler, water spread test

\section{Introduction}

Water is the most very important for living things. There is same amount of water on earth today as there was when the earth was formed. However, with increase in human and cattle population, the demand for food fiber and fodder has been increasing. As a result, water resources are progressively getting exhausted and competition for available water between agriculture[1], the domestic and industrial sectors is increasing day by day [2].

Irrigation is one of the innovations of irrigation methods that can be used for dry land [3].

In this study, the operation of irrigation water is carried out automatically using a valve as an actuator that functions to open and close the water flow automatically with the help of a smart phone and a microcontroller as a controller that gives orders to the actuator to open or close.

The purpose of this study was to test the performance of the automatic irrigation system through the jets generated by the sprinkler on the experimental plot scale.

\section{Material and Methods}

Sprinkler is a watering tool that does not require much human labor, so it is often used in large areas. The work unit consists of three basic components, namely a pump, pipap and sprinkler [4]. Bulk irrigation consists of several components, namely propulsion, main pipe, lateral pipe and sprinkler head [5].

Internet of Things (IoT) is a concept in which certain objects have the ability to transfer data via a network (android) without requiring human to human or human to computer interaction [6]. There are various capabilities for example in sharing data, being a remote control, and many others. Actually, it functions include also being applied to objects in the real world around us. Food 
processing, electronics, and various machines or other technologies that are all connected to local and global networks through embedded, always-on sensors are examples of IoT capabilities.

According to Setiawan, 2011 [7] the microcontroller is a device that is tasked with carrying out the commands given to it. Microcontroller is the main part of a computerized program. The program gives commands to the computer to work on a long relationship of certain functions to carry out complex tasks created by the program.

The microcontroller hardware required in designing this IoT (Internet of Things) based irrigation system is as follows:

\subsection{ESP8266 NodeMCU}

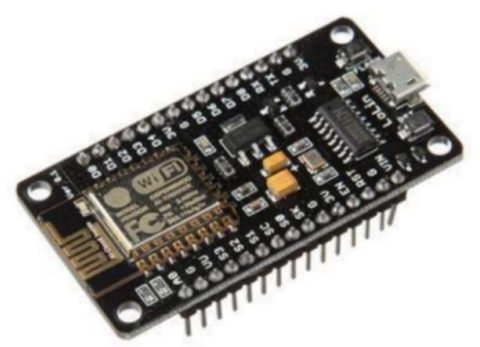

Figure 1. ESP8266 NodeMCU v3

Source: www.instructables.com

ESP8266 is an electronic platform that is open source, based on flexible software and hardware, and is easy to use. ESP8266 as an open source physical computing platform on a simple I / O board, physical computing is an interactive physical system with software and hardware users that can detect and respond to situations and conditions. The ESP8266 NodeMCU itself is equipped with a micro usb port which functions to program and provide power supply. Apart from that it is equipped with buttom push for reset and flash. Programming on the ESP8266 NodeMCU board uses the same programming language as Arduino, namely the $\mathrm{C} / \mathrm{C}++$ language, for programming development it also supports the Arduinom IDE software. This board is equipped with a WiFi feature along with its open source firmware. So it is easy to use in the development of IoT based microcontrollers, because all circuits are on one board [8].

\subsection{Water Flow Sensor / Flow Meter}

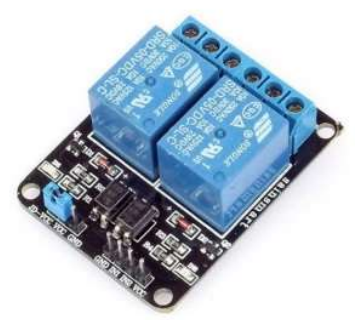

Figure 2. Water Flow Meter $1 / 2$ Inch

Source: create.arduino.cc

Water flow sensor is part of the microcontroller component that is used to read the flow of a substance. This substance can be a liquid or a gas in a certain container. Water flow sensors are used for measurements that produce a value, namely the value of water discharge and the value of the volume of water flowing through the sensor turbine [9]. 


\section{Result and Discussion}

\subsection{Description of the Research Area}

Research and assembly of tools were carried out at the Environmental-Hydro Laboratory of the Civil Engineering, University of Islamic Malang with rice fields located on Green Tombro Street, Tasikmadu, Lowokwaru District, Malang City, Indonesia.

\subsection{Necessary data:}

- Discharge data;

- The water level in the reservoir as a reference;

- Automatic sprinkler spacing;

- The experiment is repeated 10 times for each sprinkler and 4 sprinklers are used.

\subsection{Steps:}

\section{$>$ System Design Analysis and Design}

At this stage, an analysis of the hardware and software design requirements will be carried out. The system design that is made will be adjusted to the needs analysis that has been carried out starting from evaluating the problem to determining the goals and targets of later users of this software.

\section{Tools}

This stage is the stage where some materials are needed for the design of the microcontroller hardware to build the sprinkler irrigation system software.

\section{$>$ Testing the Water Distribution System}

At this stage, the software used is the Arduino IDE and Blynk

\section{$>$ Irrigation Network}

In open irrigation systems the conduit network consists of the main canal and interfarm and aintrafarm distribution canals of various levels. The main canals supplies water from a river, reservoir, well, or other source to the interfarm distribution canals, which supplies it to the separate farms or corporation sectors, the intrafirm distribution canals deliver water to the fields of the rotation or to irrigation sectors. Cases the supply network does not have a full complement of canals. The irrigation canals are arranged in such a way as to minimize construction and operation costs while providing for the supply of water in the required quantities and at the required times, as well as maximum canal efficiency (the ratio of water discharge at the end of the canal to discharge at the beginning). Other goals are to maximize the land use ratio of the irrigated areas and to provide for efficient operation of the canals and structures on such area. An essential condition for the operation of an irrigation network is that the main canal have a water level higher than that of canals of lower ranks and that higher ranking canals be higher than lower ranking canals so that the water flows by gravity. 


\section{JICEJournal Innovation of Civil Engineering}

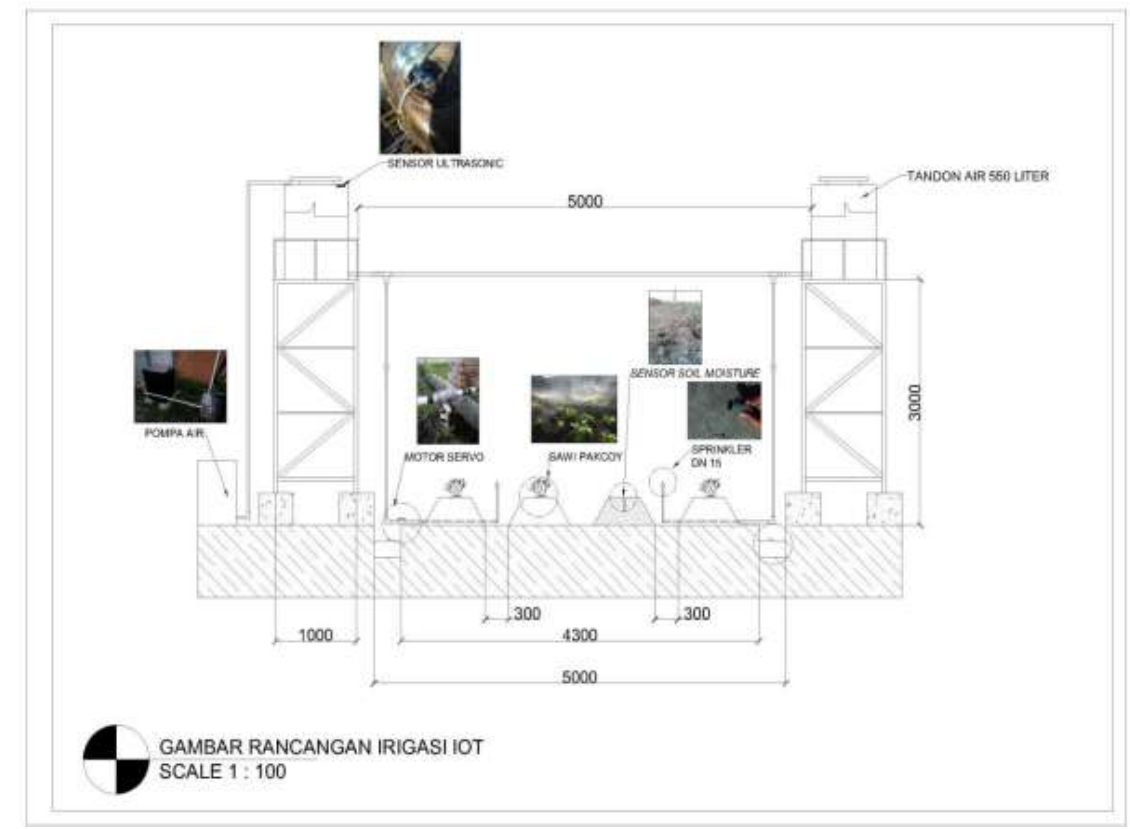

Figure 3. Irrigation Sprinkler Installation Scheme

Experiments were carried out on land with an area of $10 \times 8 \mathrm{~m} .4$ sprinklers are installed with a distance of $1 \mathrm{~m}$. This irrigation sprinkler design uses a water pump and utilizes the force of gravity in the presence of a height difference from reservoir to land.

Figure 3 shows a schematic of the irrigation sprinkler system installation and its piping in the field.

\subsection{Sprinkler Water Spread}

The sprinkler distance measurement uses the circle formula as follows:

$L=\pi r^{2}$

$L=3,14 \times 1,358^{2}$

$L=5,7907 \mathrm{~m}^{2}$

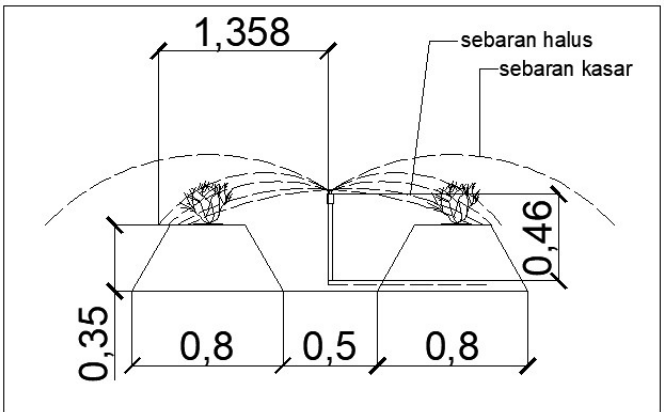

Figure 4. Sprinkler Water Spread 
Table 1. Sprinkler Water Spread Measurement Results

\begin{tabular}{|c|c|c|c|c|c|c|c|c|}
\hline \multirow{2}{*}{$\begin{array}{c}\text { Tinggi } \\
\text { Air } \\
\text { (cm) }\end{array}$} & \multicolumn{2}{|c|}{$\begin{array}{c}\text { Lemparan Sprinkler } \\
1\end{array}$} & \multicolumn{2}{|c|}{$\begin{array}{l}\text { Lemparan Sprinkler } \\
2\end{array}$} & \multicolumn{2}{|c|}{$\begin{array}{l}\text { Lemparan Sprinkler } \\
\qquad 3\end{array}$} & \multicolumn{2}{|c|}{$\begin{array}{l}\text { Lemparan Sprinkler } \\
\qquad 4\end{array}$} \\
\hline & $\begin{array}{l}\text { Otomatis } \\
90^{\circ}(\mathrm{m})\end{array}$ & $\begin{array}{l}\text { Manual } \\
90^{\circ}(\mathrm{m})\end{array}$ & $\begin{array}{l}\text { Otomatis } \\
90^{\circ}(\mathbf{m})\end{array}$ & $\begin{array}{l}\text { Manual } \\
90^{\circ}(\mathrm{m})\end{array}$ & $\begin{array}{l}\text { Otomatis } \\
90^{\circ}(\mathrm{m})\end{array}$ & $\begin{array}{l}\text { Manual } \\
90^{\circ}(\mathrm{m})\end{array}$ & $\begin{array}{l}\text { Otomatis } \\
90^{\circ}(\mathrm{m})\end{array}$ & $\begin{array}{l}\text { Manual } \\
90^{\circ}(\mathrm{m})\end{array}$ \\
\hline 90 & 1.358 & 1.405 & 1.358 & 1.405 & 1.350 & 1.402 & 1.350 & 1.402 \\
\hline 85 & 1.305 & 1.354 & 1.305 & 1.354 & 1.300 & 1.350 & 1.300 & 1.350 \\
\hline 80 & 1.258 & 1.307 & 1.258 & 1.307 & 1.250 & 1.302 & 1.250 & 1.300 \\
\hline 75 & 1.209 & 1.254 & 1.209 & 1.250 & 1.204 & 1.254 & 1.204 & 1.254 \\
\hline 70 & 1.153 & 1.208 & 1.150 & 1.200 & 1.153 & 1.202 & 1.153 & 1.202 \\
\hline 65 & 1.102 & 1.153 & 1.102 & 1.153 & 1.102 & 1.155 & 1.102 & 1.155 \\
\hline 60 & 1.506 & 1.105 & 1.506 & 1.105 & 1.105 & 1.506 & 1.051 & 1.100 \\
\hline 55 & 1.007 & 1.054 & 1 & 1.054 & 1.054 & 1.007 & 1.007 & 1.053 \\
\hline 50 & 0.956 & 1 & 0.956 & 1 & 1 & 0.956 & 0.956 & 11.002 \\
\hline 45 & 0.903 & 0.953 & 0.903 & 0.950 & 0.950 & 0.90 & 0.90 & 0.953 \\
\hline
\end{tabular}

\subsection{Two Variable $T$ Test}

$\mathrm{T}$ test or partial test is used to determine whether there is an influence between the independent (free) variable and the dependent (dependent) variable individually. From the results of the T test, it can be concluded whether the results of manual and automatic discharge are appropriate and there is no real difference, this test will be used for other variables. this is to be a reference in analyzing the performance of microcontroller-based automatic sprinkler irrigation tools [10].

The value of $\mathrm{T}$ count $<\mathrm{T}$ - table means that $\mathrm{H}_{\mathrm{o}}$ is accepted (there is no significant difference). From the observation results of the manual and automatic sprinkler distribution using a water flow sensor, the $\mathrm{T}$ test results are obtained by analyzing there is no significant difference which means that the two experiments have almost the same results.

\section{Conclusions}

$>$ An automatic bulk irrigation system based on micro-controllers has been developed and tested at an experimental plot scale. The sensor can function properly because the distribution of water using openings manually and using automatically statistically fulfills the $\mathrm{T}$ test.

$>$ The results of measuring the distance of sprinkler distribution in the field automatically and manually.
a. Total sprinkler distribution 1 to 4 openings 900 manual field data $=47,115 \mathrm{~m}$;
b. Total sprinkler distribution 1 to 4 openings 900 automatic field data $=46,505 \mathrm{~m}$;
c. Total sprinkler distribution 1 to 4 openings 900 manual calculated using circle area $=$ $176,8605 \mathrm{~m}^{2}$;
d. Total sprinkler distribution 1 to 4 openings 900 automatically calculated using the circle area $=173,5097 \mathrm{~m}^{2}$.


$>$ The results of measuring the spread of automatic and manual sprinklers show that the results are not much different, only a difference of $1 \%$ so that the performance of both automatic and manual sprinklers has not much different results.

\section{References}

[1] D. L. Bjorneberg, "IRRIGATION | Methods," in Reference Module in Earth Systems and Environmental Sciences, 2013.

[2] Available:http://www.fao.org/docrep/016/ap106e/ap106e.pdf

[3] http://jurnalirigasi_pusair.pu.go.id/index.php/jurnal_irigasi/article/view/74

[4] Najiyati and Danarti. "Kopi Budidaya dan Penanganan Lepas Panen”, Edisi Revisi. Jakarta. Penebar Swadaya. 2004.

[5] Dinesh K, "Food security and sustainable agriculture in India", The Water Management Challenge, pp. 17-18, 2019.

[6] Sharma, Subedar, "Integrated water management irrigation methods", IARI, New Delhi, pp. 33-34, 2010.

[7] A. Setiawan, "Mikrokontroler ATMEGA 8535 \& ATMEGA16 menggunakan. BASCOMAVR", Andi: Yogyakarta, 2011.

[8] D. Dhan, M. Imtiyaz, "Performance Evaluation of Micro-Sprinkler System Under Different Arrangements", Society for Development in Agriculture and Technology, pp.268, 2009.

[9] K. Demirel, S. Sener, "Performance of Sprinkler Irrigation Systems At Different Pressures And Under Varying Wind Speed Conditions in Landscape Areas", Philippine Agricultural Scientist, pp. 308-314, 2009.

[10] E. Noerhayati, FA. Sinaga, B. Suprapto, "Studi Alternatif Perencanaan Jaringan Irigasi Curah (Sprinkler Irigation)”, Jurnal Rekayasa Sipil 7 (1), pp. 23-32, 2019. 